\title{
Lymphomatoid Granulomatosis in a Patient with Rheumatoid Arthritis Receiving Methotrexate: Successful Treatment with the Anti-CD20 Antibody Mabthera
}

\author{
Enrico Schalk Christian Krogel Katrin Scheinpflug Martin Mohren \\ Klinik für Hämatologie/Onkologie, Universitätsklinikum Magdeburg, Germany
}

The risk for malignant lymphoproliferative diseases (LPD), particularly aggressive lymphoma, is increased in patients with rheumatoid arthritis (RA). Chronic B cell activation due to chronic inflammation, long-term use of immunosuppressive drugs such as methotrexate (MTX) as well as Epstein-Barr virus $(\mathrm{EBV})$ infection have been proposed as the etiologic cause $[1,2]$.

Lymphomatoid granulomatosis (LYG) is a rare, angiocentric and angiodestructive, EBV-driven LPD involving extranodal sites. Patients with underlying immunodeficiency are at increased risk. Predisposing conditions include allogenic organ transplantation, Wiskott-Aldrich syndrome, human immunodeficiency virus infection, and X-linked lymphoproliferative syndrome. The clinical course is extremely variable, ranging from an indolent form to a disease that is similar to aggressive lymphoma. Due to the rarity of the disease, there is no standard treatment. Interferon (IFN) $\alpha-2 b$ is usually recommended for treatment of $\mathrm{LYG} \mathrm{I}-\mathrm{II}^{\circ}$, whereas $\mathrm{LYG} \mathrm{III}^{\circ}$ is treated with combination chemotherapy used in aggressive $\mathrm{B}$ cell lymphoma, e.g. CHOP (cyclophosphamide, doxorubicin, vincristine, and prednisone) [3, 4]. Mabthera, a humanised monoclonal antibody, targets the B cell CD20 antigen and causes rapid and specific B cell depletion. It has been used for the treatment of CD20-positive non-Hodgkin's lymphomas usually in combination with cytotoxic drugs and has recently been approved for treatment of RA as well $[5,6]$.

Here, we report on a patient with RA who developed LYG under MTX therapy who was successfully treated with mabthera.

\section{Case Report}

A 74-year-old woman with a 28-year history of RA had been treated with a variety of antirheumatic drugs (piroxicam, prednisolone, leflunomide, meloxicam and MTX). She was receiving MTX $20 \mathrm{mg} / \mathrm{week}$ and mel-

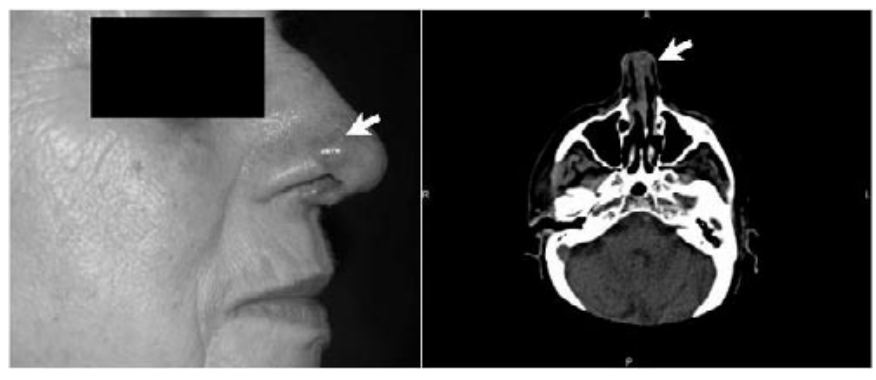

Fig. 1. Left: Tumour-like lesion of the nasal skin (arrow); right: computed tomography scan of the head shows a thickness of the nasal septum (arrow).

oxicam $15 \mathrm{mg} /$ day for 21 months, showing little inflammatory activity of the RA when she complained about impaired nasal breathing and a tumour-like lesion of the nasal wing. Computed tomography showed a mass in the nasal septum (fig. 1). Histologic examination revealed LYG II . EBV-nuclear-IgG and EBV-capsid-IgG were positive whereas EBV-capsid-IgM was negative, consistent with prior but not acute EBV infection. MTX was discontinued immediately. Since IFN- $\alpha$ has been implicated in the activation of arthritis [7], we felt reluctant to its use. However, CHOP seemed too aggressive in this elderly patient with low-grade LYG. Because of its effectiveness in the treatment of B cell lymphoma as well as RA, we decided to give 4 doses of mabthera $375 \mathrm{mg} / \mathrm{m}^{2}$ weekly. Complete remission (CR) of LYG was confirmed 4 weeks after the last dose. 19 months later, the patient was in ongoing CR of LYG and shows no clinical signs of active RA under sulfasalazine $2000 \mathrm{mg}$ /day.

\section{Discussion}

The successful use of mabthera in LYG was first published in 2003 by Sebire et al. [8]. Further reports followed showing ongoing CR for up to 36 months $[9,10]$. However, all patients reported in these publications had no underlying chronic autoimmune disease such as RA. Therefore, this is the first report of the use of an anti-CD20 antibody in a patient with RA who had developed LYG and achieved CR after only 4 doses.

\section{KARGER}

Fax +497614520714

Information@Karger.de

www.karger.com (c) 2009 S. Karger GmbH, Freiburg

Accessible online at:

www.karger.com/onk 
It is still unclear if the higher risk for LPD in patients with RA is associated with the use of immunosuppressive therapy and whether drugs like MTX, cyclosporine A or azathioprine should be discontinued if LPD occurs. Since it has been noted that the risk of LPD in patients with RA correlates with disease activity, chronic inflammation itself leading to polyclonal and possibly subsequent monoclonal B cell activation may play a major role in lymphomagenesis $[1,6,11]$. Thus, control of inflammation and antiproliferative treatment seem warranted in this condition.

Since EBV-infected B cells in patients with LYG highly express CD20 [3], they are rapidly eliminated by antibodydependent and complement-mediated cytotoxicity if exposed to mabthera $[5,6,8,12]$. In all reports published to date, mabthera was effective and well tolerated in EBV-driven LPD. Overall response rates ranged from 20 to $100 \%$. Yet, early relapses were seen in about $25 \%[8,12,13]$, indicating that the anti-CD20 antibody alone may not be sufficient to cure this disease $[12,13]$. In our patient, mabthera proved to be a very effective therapeutic alternative, successfully treating both LYG and RA at the same time.

\section{Conflict of Interest}

No conflict of interests to disclose.

\section{References}

1 Baecklund E, Iliadou A, Askling J, Ekbom A, Backlin C, Granath F, Catrina AI, Rosenquist R, Feltelius N, Sundström C, Klareskog L: Association of chronic inflammation, not its treatment, with increased lymphoma risk in rheumatoid arthritis. Arthritis Rheum 2006;54:692-701.

2 Wolfe F, Michaud K: The effect of methotrexate and anti-tumor necrosis factor therapy on the risk of lymphoma in rheumatoid arthritis in 19,562 patients during 89,710 person-years of observation. Arthritis Rheum 2007;56:1433-1439.

3 Pittaluga S, Wilson WH, Jaffe ES: Lymphomatoid granulomatosis; in Swerdlow SH, Campo E, Harris NL, Jaffe ES, Pileri SA, Stein H, Thiele J, Vardiman JW (eds): WHO Classification of Tumours of Haematopoietic and Lymphoid Tissues, vol 4. Lyon, IARC Press, 2008, pp 247-249.

4 Brown JR, Skarin AT: Clinical mimics of lymphoma. Oncologist 2004;9:406-416.

5 Rastetter W, Molina A, White CA: Rituximab: expanding role in therapy for lymphomas and autoimmune diseases. Annu Rev Med 2004;55:477-503.
6 Dörner T: Crossroads of B cell activation in autoimmunity: rationale of targeting B cells. J Rheumatol 2006;33(suppl 77):3-11.

7 Kötter I, Müller CA, Einsele H, Mohren M, Kanz L: Interferon- $\alpha$-associated polyarthritis. Possible induction of seropositive rheumatoid arthritis by interferon- $\alpha$ : two case reports and review of the literature. Z Rheumatol 1999;58;185-195.

8 Sebire NJ, Haselden S, Malone M, Davies EG, Ramsay AD: Isolated EBV lymphoproliferative disease in a child with Wiskott-Aldrich syndrome manifesting as cutaneous lymphomatoid granulomatosis and responsive to anti-CD20 immunotherapy. J Clin Pathol 2003;56:555-557.

$\checkmark$ Zaidi A, Kampalath B, Peltier WL, Vesole DH: Successful treatment of systemic and central nervous system lymphomatoid granulomatosis with rituximab. Leuk Lymphoma 2004;45:777-780.

10 Jordan K, Grothey A, Grothe W, Kegel T, Wolf $\mathrm{HH}$, Schmoll HJ: Successful treatment of mediastinal lymphomatoid granulomatosis with rituximab monotherapy. Eur J Haematol 2005;74:263-266.
11 Stewart M, Malkovska V, Krishnan J, Lessin L, Barth W: Lymphoma in a patient with rheumatoid arthritis receiving methotrexate treatment: successful treatment with rituximab. Ann Rheum Dis 2001;60:892-893.

12 Oertel S, Riess H: HIV-assoziierte Lymphome und posttransplantationslymphoproliferative $\mathrm{Er}$ krankungen (post transplant lymphoproliferative disorders, PLTD); in Hiddemann W, Dreyling M, Stein H (eds): Lymphome. Neue Erkenntnisse und Therapiestrategien, Vol 1. Stuttgart, Thieme, 2005, pp 169-186.

13 Gottschalk S, Rooney CM, Heslop HE: Infectious mononucleosis and other Epstein-Barr virus-associated diseases; in Hoffman R, Benz EJ, Shattil SS, Furie B, Cohen HJ, Silberstein LE, McGlave P (eds): Hematology: Basic Principles and Practice, vol 4. Philadelphia, Elsevier, 2005, pp 891-900. 